\title{
VALUATION OF EQUITY RELEASE CONTRACTS IN CZECH REPUBLIC, REPUBLIC OF POLAND AND SLOVAK REPUBLIC*
}

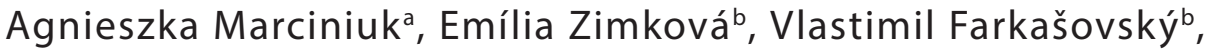 Colin W. Lawson ${ }^{\text {b,c }}$}

\begin{abstract}
An ageing European population and, therefore, a rising dependency ratio of retirees to the working population, strongly suggests that a pension funding gap will be a key social issue in future. Yet many older people have significant real estate assets that they could access using equity release products. They could sell their assets in exchange for lifelong or temporary monthly payments. Equity release products are relatively new to Poland, but are not yet offered by commercial banks in Czechia and Slovakia. This paper estimates the potential benefits of marriage reverse annuity, and reverse mortgage contracts, using the Svensson model function, and empirical property data from selected Czech, Slovak and Polish cities. The results are also compared to the average pension of inhabitants in the selected cities. It is shown that there is substantial scope for boosting retirement income in all the cases considered, though the precise size of the increase depends on factors such as contract buyers' age and life expectancy, the value of their assets, the payment consequences of a spouse's death, and contract suppliers' pricing policies.
\end{abstract}

Keywords: Equity release contract, reverse annuity contract, reverse mortgage, pension funding gap, Svensson model

JEL Classification: C41, C60, G17, G22, G12, J10

\section{Introduction and Motivation}

Toussaint and Elsinga (2009) noted that there was little evidence across the European Union of significant convergence in the design of social welfare systems. However, the population

a Wroclaw University of Economics, Faculty of Management, Poland

b Matej Bel University in Banská Bystrica, Faculty of Economics, Slovak Republic

c University of Bath, United Kingdom

Email: agnieszka.marciniuk@ue.wroc.pl; emilia.zimkova@umb.sk; vlastimil.farkasovsky@umb.sk; hsscwl@bath.ac.uk

* Financial support from VEGA (Project No. 1/0785/19 Construction and analysis of dynamic nonlinear models of macroeconomic processes) is gratefully acknowledged. Financial support from VEGA (Project No. 1/0608/19 Nexus of finance and growht in Visegrad countries) is gratefully acknowledged. 
is ageing everywhere, and this increases pressure on welfare budgets. Therefore, asset-based welfare policies, such as equity release contracts, are increasingly attractive to both voters and politicians. Toussaint and Elsinga (2009) examine attitudes to the use of housing equity across eight EU countries: Hungary, Germany, Sweden, the UK, Portugal, Belgium, Finland, and the Netherlands. Drawing on 2005 data, they observe that in all these countries respondents used housing equity in a variety of ways to help plan their finances. When respondents became outright owners, their housing costs fell. Sometimes the house was sold to help achieve a new objective - obviously a form of equity release. Sometimes housing equity was passed across generations, or within generations. Finally, it might be withdrawn via a mortgage. They found that the first three uses of housing equity were common, but the last one was not. "It is only in the UK that households have adopted mortgage equity release products to cash in their housing equity for welfare needs." (ibid. p. 669)

The situation has changed since 2005, as many more people have become familiar with the idea of funding the expenses of old age by drawing down equity in housing. A range of equity release products are now available in many countries (Hannewald et al., 2016; Charupat et al., 2016). The growing market for such products reflects an ageing European population (Blake et al., 2013). However, the United Kingdom, where they were introduced over 25 years ago, remains the largest European market for equity release contracts (Shao et al., 2015). They are also available in Spain, Ireland, France, Germany and Poland. Hungary has also developed equity release contract markets (Reifner et al., 2009).

Of the three countries considered in our paper, therefore, Poland is the only one whose financial institutions offer equity release contracts, even though for some years past the legal environments in Czechia and Slovakia would have presented no special problems for their issue. This paper aims to initiate the discussion about their introduction in Czechia and Slovakia.

Currently, there are two main types of equity release products in Poland: the loan model and the sale model. In the loan model (reverse mortgage scheme), the buyer takes out a loan using the property as security. In the sale model (home reversion scheme), the buyer exchanges the property for the promise of a certain sum at regular intervals, until the buyer dies. According to Dębicka and Marciniuk (2014), Marciniuk (2017), and Marciniuk and Zimková (2018), both products are available in Poland, although equity release is not yet as popular as it is in the USA or the UK.

In Poland, initially the equity release contract was only available to individuals. Marriage life annuities or insurance for married couples was first analysed for Poland by Heilpern (2014) and extended by Luciano et al. (2016). These authors considered the dependence between spouses' future lifetimes. In Marciniuk (2017), the reverse annuity is applied to derive two lemmas used to determine marriage benefits payable 
more than once a year in the case of Last Surviving Status and Joint Life Status (when a reduction factor $F=\{0,1\}$ ) for Polish voivodeship data. As many property owners are couples, the contracts need to specify what happens when one of the spouses dies.

Our paper aims to extend current understanding in the field of equity release products by (i) extending previous valuation methodology by applying a range of possible values for a reduction factor $\mathrm{F}$ in the valuation; (ii) calculating the potential benefits of equity release products in selected Czech, Polish and Slovak cities, for both loan and sale models, and focusing on marriage contracts; and (iii) comparing the estimated potential payments from equity release contracts to the average pensions of the inhabitants of selected Czech, Slovak and Polish cities.

The novel results can be used by financial institution management, national policy makers and potential clients. The paper should also be of interest to other researchers and commentators who work on the pension funding gap issue.

The structure of the paper is as follows. After this introductory section, Section 2 sets out the methodological approach and the data. Section 3 contains empirical results and other findings. Section 4 provides conclusions and final remarks.

\section{Data and Methodology}

The potential value of equity release products depends on whether they involve a one-off payment or a series of payments, the discount fraction F, and the value of the property. We will deal with all those factors in the following section.

Numerical calculations are based on the time-dependent real interest rate function for the Svensson model, which is available from the European Central Bank (https://www.ecb.europa.eu). The market value of property in 2017 is taken from the National Bank of Slovakia and www.reality.sk for Czechia and Slovakia, and from www.bankier.pl for Poland. The Life Tables for 2014 are from www.mortality.org.

\subsection{Life expectancy in Czechia, Poland and Slovakia}

Life expectancy for all the three countries is similar and has risen in recent years. Up to the age of 60, Czechs have the longest life expectancy. At and above 60, Poles can expect to live the longest. Slovaks have the shortest life expectancy. To quantify these differences, the relative differences in life expectancy between Czechs and Poles $\left(d_{\mathrm{C} / \mathrm{P}}\right)$ and between Slovaks and Poles $\left(d_{\mathrm{S} / \mathrm{P}}\right)$ are calculated as follows:

$$
d_{\mathrm{C} / \mathrm{P}}=\frac{e_{x}^{\text {Czechia }}-e_{x}^{\text {Poland }}}{e_{x}^{\text {Poland }}} \text { and } d_{\mathrm{S} / \mathrm{P}}=\frac{e_{x}^{\text {Slovakia }}-e_{x}^{\text {Poland }}}{e_{x}^{\text {Poland }}} .
$$

Both relative differences are shown for different ages in Figure 1. 
Figure 1: Relative differences in life expectancy between Poles and Slovaks and between Poles and Czechs, in 2014

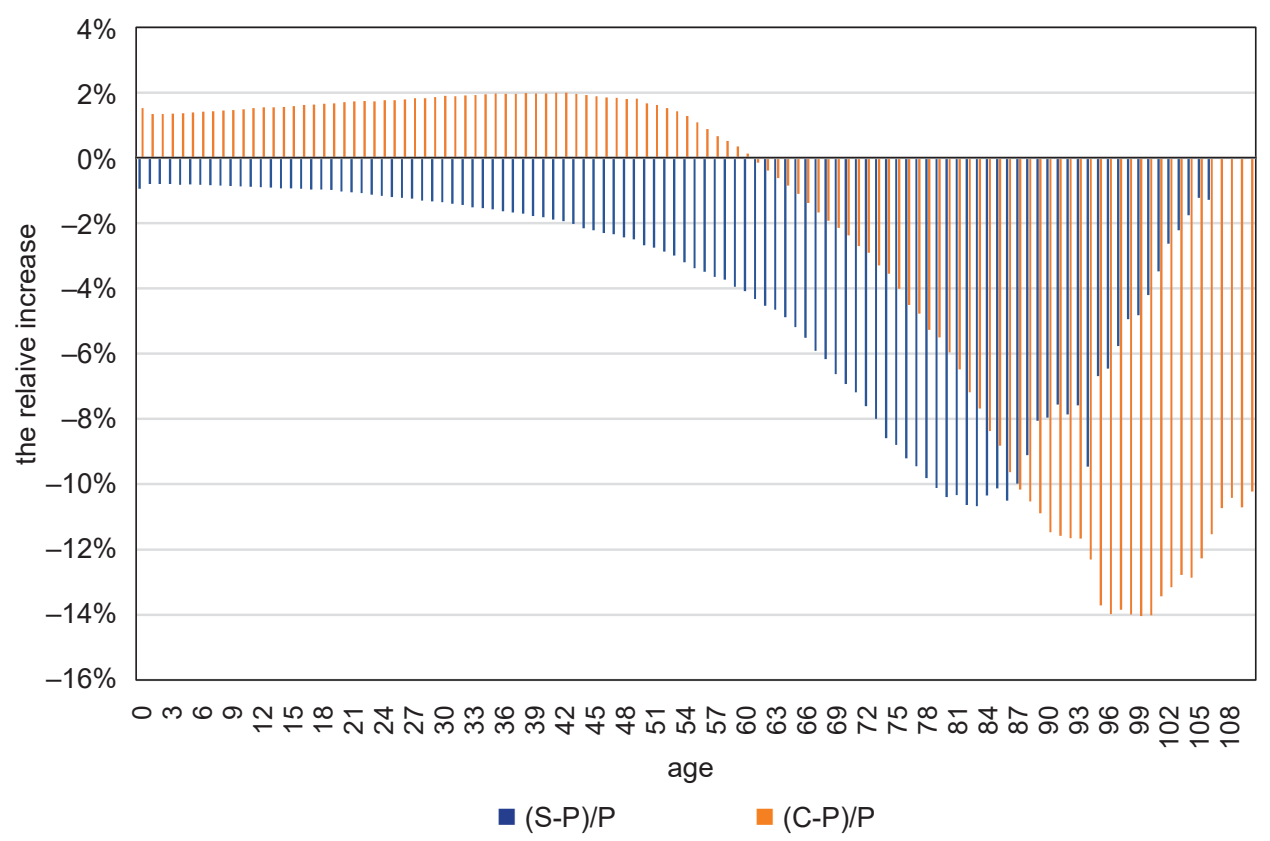

Source: Own elaboration based on www.mortality.org

For 2014, the relative difference in life expectancy between Czechs and Poles increases from $1.34 \%$ to $2 \%$, and then declines to $-14.04 \%$ before recovering to $-1.71 \%$, where a negative difference indicates that Poles live longer than Czechs. The relative difference in life expectancy between Slovaks and Poles ranges from $-1.52 \%$ to $-10.67 \%$ for ages less than or equal to 85 , and then shrinks to $0 \%$ for very elderly people.

\subsection{Prices of real estate in Czechia, Poland and Slovakia}

To compare the results for the three countries, apartments were divided into three groups by size. The first group comprised bachelor and one-room flats, up to $36 \mathrm{~m}^{2}$. The second group comprised flats in the size interval $\left(36 \mathrm{~m}^{2}, 60 \mathrm{~m}^{2}\right]$. The three-, four- and five-room flats were combined into a third group, with a size interval from $\left(60 \mathrm{~m}^{2}\right.$ to $110 \mathrm{~m}^{2}$ ]. The average price was calculated as an arithmetic mean of all the available prices in each city. These prices, in euros, are shown in Table 1. 
Table 1: Apartment prices per square metre in Poland, Slovakia and Czechia in $€$

\begin{tabular}{|c|c|c|c|c|}
\hline Size of apartment in $\mathrm{m}^{2}$ & $0-38$ & $38-60$ & $60-90$ & \\
\hline Czech cities & \multicolumn{3}{|c|}{ Price } & average price \\
\hline České Budějovice & 1,289 & 1,466 & 963 & 1,115 \\
\hline Brno & 2,485 & 2,430 & 1,345 & 2,239 \\
\hline Karlovy Vary & 929 & 1,072 & 1,345 & 1,173 \\
\hline Praha & 3,416 & 2,816 & 2,524 & 2,820 \\
\hline Hradec Králové & 1,630 & 1,749 & 1,522 & 1,646 \\
\hline Liberec & 1,224 & 1,276 & 1,411 & 1,319 \\
\hline Ostrava & 1,205 & 898 & 1,097 & 989 \\
\hline Kladno & 868 & 1,363 & 1,525 & 1,348 \\
\hline Size of apartment in $\mathrm{m}^{2}$ & $0-36$ & $36-60$ & $60-110$ & \\
\hline Slovak cities & \multicolumn{3}{|c|}{ Price } & average price \\
\hline Banská Bystrica & 1,645 & 1,441 & 1,259 & 1,334 \\
\hline Bratislava & 2,271 & 2,243 & 2,042 & 2,207 \\
\hline Košice & 1,682 & 1,530 & 1,393 & 1,565 \\
\hline Nitra & 1,939 & 1,365 & 1,271 & 1,581 \\
\hline Prešov & 1,258 & 1,139 & 1,120 & 1,263 \\
\hline Trenčín & 1,411 & 1,274 & 1,181 & 1,320 \\
\hline Trnava & 1,558 & 1,418 & 1,266 & 1,503 \\
\hline Žilina & 1,554 & 1,351 & 1,229 & 1,346 \\
\hline Size of apartment in $\mathrm{m}^{2}$ & $0-36$ & $36-60$ & $60-110$ & \\
\hline Polish cities & \multicolumn{3}{|c|}{ Price } & average price \\
\hline Gdańsk & 2,004 & 1,950 & 1,768 & 1,854 \\
\hline Katowice & 1,125 & 1,108 & 1,090 & 1,107 \\
\hline Kraków & 2,026 & 1,772 & 1,783 & 1,864 \\
\hline Lublin & 1,359 & 1,232 & 1,216 & 1,242 \\
\hline Poznań & 1,596 & 1,504 & 1,382 & 1,475 \\
\hline Szczecin & 1,233 & 1,131 & 1,080 & 1,085 \\
\hline Warszawa & 2,304 & 2,116 & 2,119 & 2,223 \\
\hline Wrocław & 1,735 & 1,554 & 1,461 & 1,525 \\
\hline
\end{tabular}

Source: Own research based on www.reality.sk and www.bankier.pl 
Unsurprisingly, capital cities are the most expensive locations. Prices in Warszawa and in Bratislava are similar, but apartment prices in Praha are the highest: $32.5 \%$ higher than in Warszawa for small apartments, and almost $24 \%$ higher for medium-sized apartments.

Table 1 reveals that the prices of apartments have a similar structure across the three countries. All the cities were chosen for their importance (political, administrative, economic and educational) and with regard to market price data availability.

\subsection{Market value of property in Czechia, Poland and Slovakia}

Let $W$ be the market value of property. Buyers of equity release products do not receive the benefits calculated based on the entire amount of $W$. They receive only a fraction (a percentage) of $W$. This percentage is denoted as $\alpha$, where a number $(1-\alpha) \cdot W$ can be understood as the cost of the product incurred by the owners, or as the providing company's income. Mortgage funds not only bear business costs (financial, operational and other) but they also take over and hence charge for maintenance, and pay the real estate tax and perpetual usufruct tax. They may add additional services, such as free health insurance, property insurance, and free legal advice. The funds also bear all costs related to real estate valuation. Therefore, $\alpha<1$; in our paper, we assume that $\alpha=0.5$.

Part of the value added of this paper is extension of previous valuation methodology by applying a range of possible values for a reduction factor $\mathrm{F}$ in the valuation of equity release products. Assume that a marriage reverse annuity contract pays one financial unit annually at the beginning of the year, as long as both spouses are alive, and a fraction $F$ of it ( $F$ is a reduction factor, $F \in[0,1]$ ) when only one member of the couple is alive. In this scheme, when $F=1$, the benefit paid is always one financial unit. This continues after one spouse's death, meaning that after one spouse's death, the other spouse gets the same benefit as when both were alive. When $F=0$, the benefit is only paid when both spouses are alive and nothing is paid if one spouse dies. If $F=1 / 2$, the surviving spouse obtains one half of a financial unit. In our paper, we consider the cases when $F \in\left\{0, \frac{1}{4}, \frac{1}{3}, \frac{1}{2}, \frac{2}{3}, \frac{3}{4}, 1\right\}$.

The benefit is calculated based on Lemma 1 (Marciniuk, 2017) as follows:

$$
\ddot{b}_{(x, y)}=\frac{\alpha W}{\ddot{a}_{(x, y)}},
$$

where $\ddot{a}_{(x, y)}$ is the value of the reversionary annuity.

The value of $\ddot{a}_{(x, y)}$ is calculated using the following formula 


$$
\begin{aligned}
& \ddot{a}_{(x, y)}=F \ddot{a}_{x}+F \ddot{a}_{y}+\ddot{a}_{x: y}(1-2 F), \\
& \ddot{a}_{x}=\sum_{k=0}^{\infty} v^{k}{ }_{k} p_{x}, \\
& \ddot{a}_{x: y}=\sum_{k=0}^{\infty} v^{k}{ }_{k} p_{x: y} .
\end{aligned}
$$

We assume that the marriage reverse mortgage is paid at the beginning of the year, for $n$ years, as long as both spouses are alive. When one partner dies, a fraction $F$ is paid. Based on the Corollary (Marciniuk, 2017), the benefit is calculated using the following formula:

$$
\ddot{b}_{(x, y): \bar{n} \mid}=\frac{\alpha W}{\ddot{a}_{(x, y): \bar{n} \mid}}=\frac{\alpha W}{F \ddot{a}_{x: \bar{n} \mid}+F \ddot{a}_{y: \bar{n} \mid}+\ddot{a}_{x: y: \bar{n} \mid}(1-2 F)},
$$

where

$$
\ddot{a}_{x: \bar{n} \mid}=\sum_{k=0}^{n-1} v^{k}{ }_{k} p_{x}, \text { and } \ddot{a}_{x: y: \bar{n} \mid}=\sum_{k=0}^{n-1} v^{k}{ }_{k} p_{x: y} .
$$

If we assume that the spouses' future lifetimes are an independent random variable, the probability ${ }_{k} p_{x: y}$ is calculated as follows:

$$
{ }_{k} p_{x: y}={ }_{k} p_{x} \cdot{ }_{k} p_{y} \text { for } k=0,1,2, \ldots
$$

The probabilities ${ }_{k} p_{x}$ and ${ }_{k} p_{y}$ are calculated from 2014 Czech, Polish and Slovak life tables, available at www.mortality.org.

To calculate the benefit, we need the rate of interest or the discounting factor $v^{k}$ for $k=0,1,2$, which occurs in Formulas (5), (6), (8) and (9). The traditional actuarial literature assumes that the interest rate is fixed for the life of the contract. However, the interest rate that will apply in the future is, of course, neither known nor constant. The most respected studies apply the stochastic interest rate to the actuarial calculations (Carriere, 2004; Deelstra, 2000; Burnecki et al., 2003; Burnecki et al., 2004).

There are two possibilities for stochastic modelling of the interest rate: actuarial and financial. They are described in Marciniuk (2009). However, it is not necessary to use stochastic interest rate models. This is a problematic issue. For example, there may be insufficient data to employ such a complicated model. It is easier to apply an interest rate that is a deterministic function of time, and used in financial theory. For example, see the Nelson-Siegel model, or the Svensson model of the spot interest rate (James and Webber, 1996). It is possible to adapt these financial models to actuarial calculations. However, first it is necessary to explain the relationship between the actuarial and financial approaches to interest rate modelling. 
The actuarial approach requires an understanding of a technical discounting function. Assume that capital $K_{t}$ is invested at the moment $t$. After $T(0 \leq t \leq T)$ years, the capital $K_{t}$ is returned. The discounting function from the time $T$ on the time $t$ is defined as follows:

$$
v_{t, T}=\frac{K_{T}}{K_{t}}, 0 \leq t \leq T \text {. }
$$

To define financial models of an interest rate, it is necessary to introduce the concept of pricing a zero-coupon bond. A zero-coupon bond is a stock sold at a discount. The profit is the difference between its nominal price and its selling price. By convention, the nominal price is one financial unit. It means that the zero-coupon holder will receive one unit of cash at the moment $T$. The price of a zero-coupon bond of the maturity $T$ at any instant $t(0 \leq t \leq T)$ is denoted by $P_{t, T}$. It is obvious that $P_{t, T}=v_{t, T}$, because

$$
v_{t, T}=\frac{K_{t}}{K_{T}}=\frac{P_{t, T}}{P_{T, T}}=\frac{P_{t, T}}{1}=P_{t, T} .
$$

Therefore, the discounting function can be described as the price of a zero-coupon bond (Marciniuk, 2009).

The spot interest rate is determined as follows (Musiela, 1988):

$$
R_{t, T}=-\ln \frac{P_{t, T}}{T-t}, 0 \leq t \leq T .
$$

The spot interest rate is a rate of return to maturity with continuous capitalization. This function can be constant, deterministic or stochastic. It can be treated as a function depending on the time $T-t$. To estimate the parameters of the spot interest rate, we use the real price of zero-coupon bonds. If the data set for such bonds is too small, the parameters of the yield curve are estimated by least squares, using data for fixedinterest bonds and treasury bills.

From (13) it is not difficult to show that

$$
P_{t, T}=\exp \left(-(T-t) \cdot R_{t, T}\right) \text {. }
$$

There are many models of the instantaneous forward rate: for example, the NelsonSiegel model, the Bliss model or the Svensson model. The latter is a modified version of the Nelson-Siegel model. The Svensson model has more parameters, which allows greater flexibility in fitting the curve to the data (James and Webber, 1996).

Based on (12) and (14), the discounting factor $v^{k}$ for $k=0,1,2, \ldots$ is given by the function $R_{0, k}$ :

$$
\begin{aligned}
& v^{k}=\exp \left(-k \cdot R_{0, k}\right), \\
& R_{0, k} \text { is a spot interest rate. }
\end{aligned}
$$


The parameters of the function $R_{0, k}$ can be estimated by least squares, using real market data, related to the yield to maturity on zero-coupon and fixed-interest bonds for each country (Anderson et al., 1996; Marciniuk, 2017). As Slovakia belongs to the euro area, and moreover the Solvency II Directive (2009) requires the use of the European Central Bank's spot interest rates in certain insurance contracts, the best-fitting model of spot interest for the euro area real data and the parameters of $R_{0, k}$ was taken from the European Central Bank ${ }^{1}$.

The Svensson model of spot interest rates was used. The function $R_{0, k}$ has the following form (De Rezende et al., 2013):

$$
R_{0, k}=\beta_{0}+\beta_{1} \frac{\tau_{1}}{k}\left(1-e^{-\frac{k}{\tau_{1}}}\right)+\beta_{1}\left(\frac{\tau_{1}}{k}\left(1-e^{-\frac{k}{\tau_{1}}}\right)-e^{-\frac{k}{\tau_{1}}}\right)+\beta_{3}\left(\frac{\tau_{2}}{k}\left(1-e^{-\frac{k}{\tau_{2}}}\right)-e^{-\frac{k}{\tau_{2}}}\right),
$$

where $\beta_{0} \geq 0, \beta_{0}+\beta_{1} \geq 0, \tau_{1}, \tau_{2}>0$.

The parameters of this function, for 5 February 2018, are as follows:

$$
\beta_{0}=0.01781, \beta_{1}=-0.02382, \beta_{2}=0.024034, \beta_{3}=-0.26857, \tau_{1}=2.15465, \tau_{2}=2.11922 \text {. }
$$

The parameter $\beta_{0}$ is the long-term interest rate.

\section{Results and Findings}

In this section, we present a sample of numerical examples using the market data presented above. Annual marriage reverse annuity payments in euros were calculated for a range of circumstances, using own programs written in MATLAB.

Let $x$ denote the man's age and $y$ denote the woman's age, $\alpha=50 \%$ and the real value of property is the same in all the countries, i.e., value $=100,000$ euros. Table 2 reveals the annual payments from a marriage reverse annuity contract for different $x, y$ and $F \in\left\{0, \frac{1}{4}, \frac{1}{3}, \frac{1}{2}, \frac{2}{3}, \frac{3}{4}, 1\right\}$.

It can be observed that the benefit decreases as the fraction $F$ rises. For the oldest couples, the benefit when $F=1$. is almost twice that for $F=0$. The man's age has a higher impact on the benefit, because men die younger than women.

Slovaks receive the highest annual payment for contracting their property, because they have the shortest future life expectation (Figure 1). The smallest annual payment is almost always for Poles, when $F<0.5$.

1 https://www.ecb.europa.eu/stats/financial_markets_and_interest_rates/euro_area_yield_curves/ $\mathrm{html} /$ index.en.html 
Table 2: Annual marriage reverse annuity payments for property valued at 100,000 euros

\begin{tabular}{|c|c|c|c|c|c|c|c|}
\hline & 0 & $1 / 4$ & $1 / 3$ & $1 / 2$ & $2 / 3$ & $3 / 4$ & 1 \\
\hline & \multicolumn{7}{|c|}{$x=65, y=65$} \\
\hline Czechia & $3,979.5$ & $3,432.1$ & $3,281.7$ & $3,017.1$ & $2,792.1$ & $2,691.7$ & $2,429.6$ \\
\hline Poland & $4,045.0$ & $3,452.6$ & $3,291.9$ & $3,011.5$ & $2,775.2$ & $2,670.4$ & 2,398.7 \\
\hline \multirow[t]{2}{*}{ Slovakia } & $4,222.9$ & $3,605.9$ & $3,438.4$ & $3,146.2$ & 2,899.7 & $2,790.5$ & $2,507.0$ \\
\hline & \multicolumn{7}{|c|}{$x=65, y=70$} \\
\hline Czechia & $4,433.6$ & $3,806.4$ & $3,635.0$ & $3,334.7$ & $3,080.2$ & $2,967.0$ & $2,672.3$ \\
\hline Poland & $4,457.4$ & $3,801.1$ & $3,623.3$ & $3,313.3$ & $3,052.1$ & $2,936.4$ & $2,636.5$ \\
\hline \multirow[t]{2}{*}{ Slovakia } & $4,729.6$ & $4,020.6$ & $3,829.2$ & $3,496.4$ & $3,216.8$ & $3,093.1$ & $2,773.3$ \\
\hline & \multicolumn{7}{|c|}{$x=65, y=75$} \\
\hline Czechia & $5,221.4$ & $4,348.0$ & $4,118.4$ & $3,724.9$ & $3,400.1$ & $3,258.0$ & $2,895.1$ \\
\hline Poland & $5,174.1$ & $4,306.8$ & $4,078.9$ & $3,688.6$ & $3,366.4$ & $3,225.5$ & $2,865.8$ \\
\hline \multirow[t]{2}{*}{ Slovakia } & $5,593.4$ & $4,610.9$ & $4,355.9$ & $3,922.0$ & $3,566.7$ & $3,412.2$ & $3,019.7$ \\
\hline & \multicolumn{7}{|c|}{$x=70, y=65$} \\
\hline Czechia & $4,578.0$ & $3,819.3$ & $3,619.3$ & $3,276.3$ & $2,992.6$ & $2,868.4$ & $2,550.9$ \\
\hline Poland & $4,626.5$ & $3,820.2$ & $3,610.5$ & $3,253.2$ & 2960.3 & $2,832.8$ & $2,508.6$ \\
\hline \multirow[t]{2}{*}{ Slovakia } & $4,879.9$ & $4,020.9$ & $3,798.0$ & $3,419.0$ & $3,108.8$ & $2,973.9$ & $2,631.3$ \\
\hline & \multicolumn{7}{|c|}{$x=70, y=70$} \\
\hline Czechia & $4,978.8$ & $4,214.8$ & $4,009.7$ & $3,654.1$ & $3,356.4$ & $3,225.0$ & $2,886.2$ \\
\hline Poland & $4,994.3$ & $4,189.6$ & $3,976.0$ & $3,608.2$ & $3,302.6$ & $3,168.5$ & $2,824.3$ \\
\hline \multirow[t]{2}{*}{ Slovakia } & $5,340.0$ & $4,465.2$ & $4,234.0$ & $3,836.6$ & $3,507.5$ & $3,363.2$ & $2,993.8$ \\
\hline & \multicolumn{7}{|c|}{$x=70, y=75$} \\
\hline Czechia & $5,708.4$ & $4,791.2$ & $4,547.7$ & $4,128.0$ & $3,779.2$ & $3,626.0$ & $3,232.9$ \\
\hline Poland & $5,663.0$ & $4,727.9$ & $4,481.2$ & $4,057.8$ & $3,707.5$ & $3,554.1$ & $3,161.6$ \\
\hline \multirow[t]{2}{*}{ Slovakia } & $6,154.1$ & $5,100.7$ & $4,825.4$ & $4,355.3$ & $3,968.6$ & $3,799.9$ & $3,370.2$ \\
\hline & \multicolumn{7}{|c|}{$x=75, y=70$} \\
\hline Czechia & $5,889.6$ & $4,787.8$ & $4,506.7$ & $4,033.3$ & $3,649.8$ & $3,484.2$ & $3,066.7$ \\
\hline Poland & $5,829.3$ & $4,706.3$ & $4,422.3$ & $3,946.1$ & $3,562.5$ & $3,397.3$ & $2,982.5$ \\
\hline Slovakia & $6,326.6$ & $5,071.5$ & $4,756.9$ & $4,231.9$ & $3,811.3$ & $3,630.8$ & $3,179.2$ \\
\hline
\end{tabular}

Source: Own research

Moving on to calculate the value of annuities across all of the select cities: we use the example where spouses are aged 60, and when benefit is paid only when both spouses are alive (i.e., $F=0$ ). The marriage reverse annuity is calculated using the average market price per square metre, for apartments of 30, 60 and $90 \mathrm{~m}^{2}$ (Table 2). 
Figure 2: Annual payments: marriage reverse annuity payments for selected cities, $F=0$ and $x=y=60$
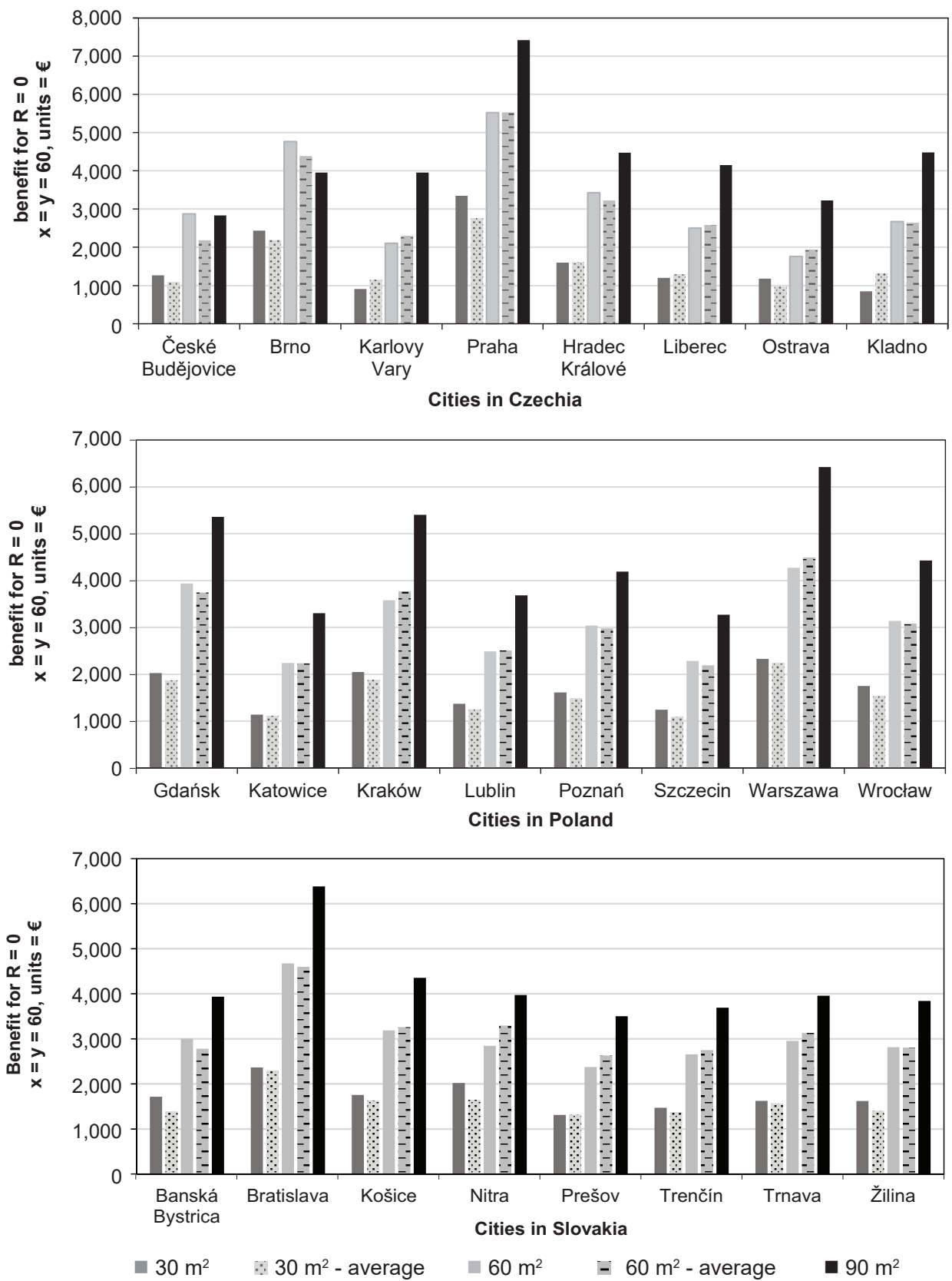

Source: Own research 
The annuities strictly depend on where the spouses live. The highest values are in the respective state capitals, with Praha in the lead. In this case, the relative size of the differences in annuities decreases between Praha and Warszawa as the size of flats increases. It is $33 \%$ for a small flat; $25 \%$ for a medium-sized flat, and $16.5 \%$ for a large apartment.

What these results emphasise is the variation in apartment values across cities within a country for a specific apartment size, and how that affects the ability of couples to increase their annual income streams. For example, for the largest apartment size, this increase is 6,434 euros in Warszawa, but only 3,304 euros in Katowice. For the smallest size of apartment in Brno, the increase is greater than for the largest apartment size in Karlovy Vary. Similarly, the increase in Praha for small flats is greater than for the largest apartment size in Ostrava.

Marriage reverse annuities in Czechia, calculated from average prices, are slightly higher than those calculated from the value of a medium-sized flat in Karlovy Vary, Praha, Liberec and Ostrava. Reverse annuities in Poland, calculated assuming average prices, are slightly smaller than those calculated from the value of a medium-sized flat, except in Kraków and Warszawa, where they are a little higher. In Slovakia, an annuity calculated using the average sale price is slightly higher than that for a medium-sized flat, except in Banská Bystrica and Bratislava, where the annuity is a little smaller. These slight variations in results reflect the overall pattern of the apartment stocks across different cities, and variations in the pattern of sales across different apartment size groups.

We also calculated the annual payments of reverse marriage annuity contracts, and their relative increase, for a 10-year marriage reverse mortgage contract. Table 3 shows the calculated annual payments for different ages $x, y$, and for $F \in\left\{0, \frac{1}{4}, \frac{1}{3}, \frac{1}{2}, \frac{2}{3}, \frac{3}{4}, 1\right\}$.

As with marriage reverse annuity contracts, Table 3 shows that annual payments decrease as $F$ rises and increase as the spouse's assumed age rises. However, the difference between the benefits for younger and more elderly borrowers varies little for a high $F$. For example, in Czechia when $F=1 \ddot{a}_{(65,65): \overline{10} \mid}=4,676.3$ and $\ddot{a}_{(75,70): \overline{10} \mid}=4,801.5$, but when $F=0$, the difference in payments between younger and more elderly borrowers is significantly higher, because $\ddot{a}_{(65,65): \overline{10} \mid}=5,583.4$ and $\ddot{a}_{(75,70): \overline{10 \mid}}=6,739.8$. For elderly borrowers, the payment rises by $40.37 \%$ when switching from an $F=1$ contract to an $F=0$. This is entirely driven by mortality data. Therefore, as we would expect (cf. Figures 1 and 2), with 10-year reverse mortgage contracts, Slovaks' relatively high benefits reflect their higher mortality, and Czechs' relatively low benefits reflect their relatively low mortality. 
Table 3 | Values of reverse marriage annuity contracts and their relative increase (\%) when calculating a 10-year marriage reverse mortgage contract in $€$

\begin{tabular}{|c|c|c|c|c|c|c|c|}
\hline $\boldsymbol{F}$ & 0 & $1 / 4$ & $1 / 3$ & $1 / 2$ & $2 / 3$ & $3 / 4$ & 1 \\
\hline & \multicolumn{7}{|c|}{$x=65, y=65$} \\
\hline Czechia & $\begin{array}{c}5,583.4 \\
(40.3)\end{array}$ & $\begin{array}{c}5,325.1 \\
(55.2) \\
\end{array}$ & $\begin{array}{c}5,244.3 \\
(59.8) \\
\end{array}$ & $\begin{array}{c}5,089.7 \\
(68.7) \\
\end{array}$ & $\begin{array}{c}4,944.0 \\
(77.1) \\
\end{array}$ & $\begin{array}{c}4,874.3 \\
(81.1) \\
\end{array}$ & $\begin{array}{c}4,676.3 \\
(92.5)\end{array}$ \\
\hline Poland & $\begin{array}{c}5,676.3 \\
(40.3)\end{array}$ & $\begin{array}{c}5,390.7 \\
(56.1)\end{array}$ & $\begin{array}{c}5,301.8 \\
(61.1)\end{array}$ & $\begin{array}{c}5,132.4 \\
(70.4) \\
\end{array}$ & $\begin{array}{c}4,973.6 \\
(79.2) \\
\end{array}$ & $\begin{array}{c}4,897.8 \\
(83.4) \\
\end{array}$ & $\begin{array}{c}4,683.7 \\
(95.3)\end{array}$ \\
\hline \multirow[t]{2}{*}{ Slovakia } & $\begin{array}{c}5,713.5 \\
(35.3) \\
\end{array}$ & $\begin{array}{c}5,417.4 \\
(50.2) \\
\end{array}$ & $\begin{array}{c}5,325.3 \\
(54.9) \\
\end{array}$ & $\begin{array}{c}5,150.4 \\
(63.7) \\
\end{array}$ & $\begin{array}{c}4,986.6 \\
(72.0) \\
\end{array}$ & $\begin{array}{c}4,908.5 \\
(75.9) \\
\end{array}$ & $\begin{array}{c}4,688.3 \\
(87.0) \\
\end{array}$ \\
\hline & \multicolumn{7}{|c|}{$x=65, y=70$} \\
\hline Czechia & $\begin{array}{c}5,796.5 \\
(30.7) \\
\end{array}$ & $\begin{array}{c}5,480.2 \\
(44.0) \\
\end{array}$ & $\begin{array}{c}5,382.2 \\
(48.1) \\
\end{array}$ & $\begin{array}{c}5,196.5 \\
(55.8) \\
\end{array}$ & $\begin{array}{c}5,023.2 \\
(63.1) \\
\end{array}$ & $\begin{array}{c}4,940.8 \\
(66.5) \\
\end{array}$ & $\begin{array}{c}4,709.1 \\
(76.2) \\
\end{array}$ \\
\hline Poland & $\begin{array}{c}5,861.7 \\
(31.5)\end{array}$ & $\begin{array}{c}5,525.6 \\
(45.4)\end{array}$ & $\begin{array}{c}5,422.0 \\
(49.6)\end{array}$ & $\begin{array}{c}5,226.0 \\
(57.8)\end{array}$ & $\begin{array}{c}5,043.6 \\
(65.3)\end{array}$ & $\begin{array}{c}4,957.1 \\
(68.8)\end{array}$ & $\begin{array}{c}4,714.6 \\
(78.8)\end{array}$ \\
\hline \multirow[t]{2}{*}{ Slovakia } & $\begin{array}{c}5,977.4 \\
(26.4) \\
\end{array}$ & $\begin{array}{c}5,608.9 \\
(39.5) \\
\end{array}$ & $\begin{array}{c}5,495.9 \\
(43.5) \\
\end{array}$ & $\begin{array}{c}5,283.1 \\
(51.1) \\
\end{array}$ & $\begin{array}{c}5,086.2 \\
(58.1) \\
\end{array}$ & $\begin{array}{c}4,993.2 \\
(61.4) \\
\end{array}$ & $\begin{array}{c}4,733.4 \\
(70.7) \\
\end{array}$ \\
\hline & \multicolumn{7}{|c|}{$x=65, y=75$} \\
\hline Czechia & $\begin{array}{c}6,245.2 \\
(19.6)\end{array}$ & $\begin{array}{c}5,797.7 \\
(33.3)\end{array}$ & $\begin{array}{c}5,662.5 \\
(37.5)\end{array}$ & $\begin{array}{c}5,410.1 \\
(45.2) \\
\end{array}$ & $\begin{array}{c}5,179.2 \\
(52.3)\end{array}$ & $\begin{array}{c}5,071.0 \\
(55.6)\end{array}$ & $\begin{array}{c}4,771.9 \\
(64.8)\end{array}$ \\
\hline Poland & $\begin{array}{c}6,265.3 \\
(21.1) \\
\end{array}$ & $\begin{array}{c}5,812.5 \\
(35.0)\end{array}$ & $\begin{array}{c}5,675.7 \\
(39.1)\end{array}$ & $\begin{array}{c}5,420.7 \\
(47.0)\end{array}$ & $\begin{array}{c}5,187.6 \\
(54.1)\end{array}$ & $\begin{array}{c}5,078.4 \\
(57.4) \\
\end{array}$ & $\begin{array}{c}4,776.8 \\
(66.7)\end{array}$ \\
\hline \multirow[t]{2}{*}{ Slovakia } & $\begin{array}{c}6,532.3 \\
(16.8) \\
\end{array}$ & $\begin{array}{c}5,998.5 \\
(30.1) \\
\end{array}$ & $\begin{array}{c}5,839.5 \\
(34.1) \\
\end{array}$ & $\begin{array}{c}5,545.4 \\
(21.4) \\
\end{array}$ & $\begin{array}{c}5,279.6 \\
(48.0) \\
\end{array}$ & $\begin{array}{c}5,156.0 \\
(51.1) \\
\end{array}$ & $\begin{array}{c}4,817.6 \\
(59.5) \\
\end{array}$ \\
\hline & \multicolumn{7}{|c|}{$x=70, y=65$} \\
\hline Czechia & $\begin{array}{c}5,908.2 \\
(29.1)\end{array}$ & $\begin{array}{c}5,550.7 \\
(45.3)\end{array}$ & $\begin{array}{c}5,440.9 \\
(50.3) \\
\end{array}$ & $\begin{array}{c}5,233.9 \\
(59.8) \\
\end{array}$ & $\begin{array}{c}5,042.1 \\
(68.5) \\
\end{array}$ & $\begin{array}{c}4,951.4 \\
(72.6)\end{array}$ & $\begin{array}{c}4,697.8 \\
(84.2) \\
\end{array}$ \\
\hline Poland & $\begin{array}{c}6,006.9 \\
(29.8) \\
\end{array}$ & $\begin{array}{c}5,618.6 \\
(47.1)\end{array}$ & $\begin{array}{c}5,500.0 \\
(52.3)\end{array}$ & $\begin{array}{c}5,277.4 \\
(62.2)\end{array}$ & $\begin{array}{c}5,072.0 \\
(71.3) \\
\end{array}$ & $\begin{array}{c}, 975.2 \\
(75.6)\end{array}$ & $\begin{array}{c}4,705.8 \\
(87.6)\end{array}$ \\
\hline \multirow[t]{2}{*}{ Slovakia } & $\begin{array}{c}6,105.6 \\
(25.1)\end{array}$ & $\begin{array}{c}5,686.4 \\
(41.4)\end{array}$ & $\begin{array}{c}5,559.2 \\
(46.4)\end{array}$ & $\begin{array}{c}5,321.1 \\
(55.6) \\
\end{array}$ & $\begin{array}{c}5,102.6 \\
(61.4) \\
\end{array}$ & $\begin{array}{c}4,999.9 \\
(68.1) \\
\end{array}$ & $\begin{array}{c}4,715.3 \\
(79.2) \\
\end{array}$ \\
\hline & \multicolumn{7}{|c|}{$x=70, y=70$} \\
\hline Czechia & $\begin{array}{c}6,124.5 \\
(23.0) \\
\end{array}$ & $\begin{array}{c}5,709.4 \\
(35.5) \\
\end{array}$ & $\begin{array}{c}5,583.2 \\
(39.2) \\
\end{array}$ & $\begin{array}{c}5,346.9 \\
(46.3) \\
\end{array}$ & $\begin{array}{c}5,129.8 \\
(52.8) \\
\end{array}$ & $\begin{array}{c}5,027.8 \\
(55.9) \\
\end{array}$ & $\begin{array}{c}4,744.6 \\
(64.4) \\
\end{array}$ \\
\hline Poland & $\begin{array}{c}6,195.2 \\
(24.0) \\
\end{array}$ & $\begin{array}{c}5,756.8 \\
(37.4) \\
\end{array}$ & $\begin{array}{c}5,624.1 \\
(41.5) \\
\end{array}$ & $\begin{array}{c}5,376.3 \\
(49.0) \\
\end{array}$ & $\begin{array}{c}5,149.4 \\
(55.9) \\
\end{array}$ & $\begin{array}{c}5,043.0 \\
(59.2)\end{array}$ & $\begin{array}{c}4,748.6 \\
(68.1) \\
\end{array}$ \\
\hline \multirow[t]{2}{*}{ Slovakia } & $\begin{array}{c}6,373.6 \\
(19.4) \\
\end{array}$ & $\begin{array}{c}5,883.3 \\
(31.8) \\
\end{array}$ & $\begin{array}{c}5,736.1 \\
(35.5) \\
\end{array}$ & $\begin{array}{c}5,462.9 \\
(42.4 \%) \\
\end{array}$ & $\begin{array}{c}5,214.6 \\
(48.7) \\
\end{array}$ & $\begin{array}{c}5,098.7 \\
(51.6) \\
\end{array}$ & $\begin{array}{c}4,780.0 \\
(59.7) \\
\end{array}$ \\
\hline & \multicolumn{7}{|c|}{$x=70, y=75$} \\
\hline Czechia & $\begin{array}{c}6,577.9 \\
(15.2)\end{array}$ & $\begin{array}{c}6,034.1 \\
(25.9) \\
\end{array}$ & $\begin{array}{c}5,872.2 \\
(29.1) \\
\end{array}$ & $\begin{array}{c}5,573.3 \\
(35.0) \\
\end{array}$ & $\begin{array}{c}5,303.3 \\
(40.3)\end{array}$ & $\begin{array}{c}5,177.9 \\
(42.8)\end{array}$ & $\begin{array}{c}4,834.9 \\
(49.6)\end{array}$ \\
\hline Poland & $\begin{array}{c}6,603.2 \\
(16.6)\end{array}$ & $\begin{array}{c}6,050.2 \\
(28.0) \\
\end{array}$ & $\begin{array}{c}5,885.9 \\
(31.1)\end{array}$ & $\begin{array}{c}5,582.6 \\
(37.6)\end{array}$ & $\begin{array}{c}5,309.1 \\
(43.2) \\
\end{array}$ & $\begin{array}{c}5,182.2 \\
(45.8) \\
\end{array}$ & $\begin{array}{c}4,835.3 \\
(52.9) \\
\end{array}$ \\
\hline \multirow[t]{2}{*}{ Slovakia } & $\begin{array}{c}6,934.2 \\
(12.7) \\
\end{array}$ & $\begin{array}{c}6,283.1 \\
(23.2) \\
\end{array}$ & $\begin{array}{c}6,092.5 \\
(26.3) \\
\end{array}$ & $\begin{array}{c}5,743.9 \\
(31.9) \\
\end{array}$ & $\begin{array}{c}5,433.0 \\
(36.9) \\
\end{array}$ & $\begin{array}{c}5,289.8 \\
(39.2) \\
\end{array}$ & $\begin{array}{c}4,902.3 \\
(45,5)\end{array}$ \\
\hline & \multicolumn{7}{|c|}{$x=75, y=70$} \\
\hline Czechia & $\begin{array}{c}6,739.8 \\
(14.4) \\
\end{array}$ & $\begin{array}{c}6,122.0 \\
(27.9) \\
\end{array}$ & $\begin{array}{c}5,940.5 \\
(31.8) \\
\end{array}$ & $\begin{array}{c}5,607.9 \\
(39.0) \\
\end{array}$ & $\begin{array}{c}5,310.6 \\
(45.5) \\
\end{array}$ & $\begin{array}{c}5,173.5 \\
(48.5) \\
\end{array}$ & $\begin{array}{c}4,801.5 \\
(56.6)\end{array}$ \\
\hline Poland & $\begin{array}{c}6,761.4 \\
(16.0) \\
\end{array}$ & $\begin{array}{c}6,134.2 \\
(30.3) \\
\end{array}$ & $\begin{array}{c}5,950.2 \\
(34.5) \\
\end{array}$ & $\begin{array}{c}5,613.4 \\
(42.3) \\
\end{array}$ & $\begin{array}{c}5,312.8 \\
(49.1) \\
\end{array}$ & $\begin{array}{c}5,174.2 \\
(52.3) \\
\end{array}$ & $\begin{array}{c}4,798.7 \\
(60.9) \\
\end{array}$ \\
\hline Slovakia & $\begin{array}{c}7,100.2 \\
(12.2) \\
\end{array}$ & $\begin{array}{c}6,362.3 \\
(25.5) \\
\end{array}$ & $\begin{array}{c}6,149.3 \\
(29.3) \\
\end{array}$ & $\begin{array}{c}5,763.4 \\
(36.2) \\
\end{array}$ & $\begin{array}{c}5,423.0 \\
(42.3) \\
\end{array}$ & $\begin{array}{c}, 267.5 \\
(45.1) \\
\end{array}$ & $\begin{array}{c}4,850.1 \\
(52.6)\end{array}$ \\
\hline
\end{tabular}

Source: Own research 
Table 4 | Annual marriage reverse mortgage payments as a percentage of average pensions in the selected cities (\%)

\begin{tabular}{l|c|c|c|c|c|c|c}
\hline $\boldsymbol{F}$ & $\mathbf{0}$ & $\mathbf{1 / 4}$ & $\mathbf{1 / 3}$ & $\mathbf{1 / 2}$ & $\mathbf{2 / 3}$ & $\mathbf{3 / 4}$ & $\mathbf{1}$ \\
\hline České Budějovice & 84.42 & 81.86 & 81.04 & 79.45 & 77.92 & 77.18 & 75.03 \\
\hline Brno & 170.16 & 165.00 & 163.34 & 160.14 & 157.05 & 155.55 & 151.22 \\
\hline Karlovy Vary & 90.81 & 88.05 & 87.17 & 85.46 & 83.81 & 83.01 & 80.70 \\
\hline Praha & $\mathbf{1 9 8 . 4 7}$ & $\mathbf{1 9 2 . 4 5}$ & $\mathbf{1 9 0 . 5 3}$ & $\mathbf{1 8 6 . 7 8}$ & $\mathbf{1 8 3 . 1 8}$ & $\mathbf{1 8 1 . 4 3}$ & $\mathbf{1 7 6 . 3 8}$ \\
\hline Hradec Králové & 125.09 & 121.29 & 120.08 & 117.71 & 115.45 & 114.35 & 111.16 \\
\hline Liberec & 100.00 & 96.96 & 95.99 & 94.11 & 92.29 & 91.41 & 88.87 \\
\hline Ostrava & 73.88 & 71.64 & 70.92 & 69.53 & 68.19 & 67.54 & 65.66 \\
\hline Kladno & 99.95 & 96.91 & 95.94 & 94.06 & 92.25 & 91.37 & 88.82 \\
\hline
\end{tabular}

\begin{tabular}{l|c|c|c|c|c|c|c}
\hline $\boldsymbol{F}$ & $\mathbf{0}$ & $\mathbf{1 / 4}$ & $\mathbf{1 / 3}$ & $\mathbf{1 / 2}$ & $\mathbf{2 / 3}$ & $\mathbf{3 / 4}$ & $\mathbf{1}$ \\
\hline Banská Bystrica & 120.34 & 116.00 & 114.62 & 111.96 & 109.42 & 108.19 & 104.66 \\
\hline Bratislava & $\mathbf{1 6 7 . 0 5}$ & $\mathbf{1 6 1 . 0 2}$ & $\mathbf{1 5 9 . 1 0}$ & $\mathbf{1 5 5 . 4 1}$ & $\mathbf{1 5 1 . 8 8}$ & $\mathbf{1 5 0 . 1 8}$ & $\mathbf{1 4 5 . 2 8}$ \\
\hline Košice & 139.55 & 134.51 & 132.92 & 129.83 & 126.88 & 125.46 & 121.37 \\
\hline Nitra & 147.11 & 141.80 & 140.12 & 136.86 & 133.75 & 132.25 & 127.95 \\
\hline Prešov & 120.52 & 116.17 & 114.79 & 112.12 & 109.57 & 108.35 & 104.82 \\
\hline Trenčín & 116.68 & 112.47 & 111.13 & 108.55 & 106.09 & 104.90 & 101.48 \\
\hline Trnava & 134.46 & 129.60 & 128.06 & 125.08 & 122.24 & 120.87 & 116.94 \\
\hline Žilina & 123.45 & 118.99 & 117.58 & 114.85 & 112.24 & 110.98 & 107.37 \\
\hline
\end{tabular}

\begin{tabular}{l|c|c|c|c|c|c|c}
\hline $\boldsymbol{F}$ & $\mathbf{0}$ & $\mathbf{1 / 4}$ & $\mathbf{1 / 3}$ & $\mathbf{1 / 2}$ & $\mathbf{2 / 3}$ & $\mathbf{3 / 4}$ & $\mathbf{1}$ \\
\hline Gdańsk & 134.91 & 130.10 & 128.58 & 125.63 & 122.81 & 121.45 & 117.54 \\
\hline Katowice & 65.01 & 62.69 & 61.95 & 60.53 & 59.18 & 58.52 & 56.64 \\
\hline Kraków & 136.57 & 131.71 & 130.16 & 127.18 & 124.33 & 122.95 & 118.99 \\
\hline Lublin & 98.75 & 95.23 & 94.12 & 91.96 & 89.90 & 88.90 & 86.04 \\
\hline Poznań & 110.13 & 106.21 & 104.96 & 102.55 & 100.26 & 99.14 & 95.95 \\
\hline Szczecin & 80.88 & 78.00 & 77.08 & 75.32 & 73.63 & 72.81 & 70.47 \\
\hline Warszawa & $\mathbf{1 5 4 . 4 1}$ & $\mathbf{1 4 8 . 9 1}$ & $\mathbf{1 4 7 . 1 6}$ & $\mathbf{1 4 3 . 7 9}$ & $\mathbf{1 4 0 . 5 6}$ & $\mathbf{1 3 9 . 0 1}$ & $\mathbf{1 3 4 . 5 3}$ \\
\hline Wrocław & 108.00 & 104.16 & 102.94 & 100.58 & 98.32 & 97.23 & 94.10 \\
\hline
\end{tabular}

Source: Own research 
As to the relative increase in benefits between 10-year marriage reverse mortgages and lifelong marriage reverse annuity contracts, Table 3 reveals significant differences, especially when payment continues unchanged after one of the spouses dies (i.e., $F=1$ ). For younger owners, the relative increase in annual payments is about $87 \%$ for Slovaks and $95 \%$ for Poles. For elderly people, the relative increase in annual payments, while they last, is still high, at around $53-61 \%$. In the case of smaller $F$, the differences between benefits are high for younger spouses, but small for the elderly, at around 12-16\%.

The reverse mortgage thus provides higher annual payments, but lasts only ten years. Its relatively short time span challenges both its customers and the wider society in ways the reverse annuity does not. Its customers face the challenge of a decision, probably one hard to assess, whether to gamble on a better lifestyle over the first ten years, with a very significant drop in income thereafter. Society faces the challenge of trading off the lower demands from relatively young pensioners against the costs of increased numbers of poorer elderly pensioners.

Table 4 shows annual marriage reverse mortgage payments as a percentage of average pension in the selected cities. The value of property is assumed to be 100,000 euros, both males and females are aged 60 , and they own an apartment of $80 \mathrm{~m}^{2}$. In all the samples of Slovak cities, and in a majority of the selected Czech and Polish cities, annual marriage reverse mortgage payments are considerably higher than pensions.

\section{Conclusion}

This paper uses a model of reversionary annuity, to calculate the benefits of two equity release contracts that are currently available in Poland: the reverse annuity contract and the reverse mortgage. The calculations also cover the putative benefits that would arise if the contracts were also available in Czechia and Slovakia. The absolute amount of the annuity depends on the apartment value, which obviously varies with its size and location. For a given apartment value, the annuity varies with the spouses' age and the actuarial contract consequences of a spouse's death. As mortality tables are drawn by country, the annuity also varies by country.

All the calculations were made using market-generated data for 2014 and 2017 and own interfaces written in MATLAB. If a spouse dies, the annual benefits are obviously very sensitive to how the contract treats that event. The fraction is the fraction of the annuity that notionally was paid to the other spouse, which will not be paid when there is only one surviving spouse. Thus, the larger the $F$, the lower the contracted annual payment. However, the older the surviving spouse, the smaller the difference. Understandably the annual benefits received from reverse time-limited mortgages are considerably 
higher than those from a reverse annuity contract. For a high $F$ and younger spouses, the differences reach almost $90 \%$.

Equity release contracts carry great risks for purchasers and for providers, but also for a society that may well have to pick up some of the consequential costs of the implicit and explicit gambles that their suppliers and buyers are taking. Some contracts are expensive, but provide significant additional financial resources for elderly people. That can be a boon when social pensions are low. They allow property holders to access some of their wealth to boost their pensions, without having to incur, at least upfront, the transaction costs of selling the property, and the possible inconvenience and transaction costs of relocating. Given ageing populations, and hence rising dependency ratios, and fiscal constraints, equity release contracts are likely to become increasingly common in Poland, and are likely eventually to be introduced in Czechia and Slovakia.

\section{References}

Anderson, N., Breedon, F., Deacon, M. et al. (1996). Estimating and Interpreting the Yield Curve. Chichester: John Wiley \& Sons. ISBN 0-471-96207-4.

Blake, D., Cairns, A., Coughlan, A. et al. (2013). The New Life Market. The Journal of Risk and Insurance, 80(3), 501-557, https://doi.org/10.1111/j.1539-6975.2012.01514.x

Burnecki, K., Marciniuk, A., Weron, A. (2004). On Annuities under Random Rates of Interest with Payments Varying in Arithmetic and Geometric Progression. Probability and Mathematical Statistics, 24(1), 1-15.

Carriere, J. F. (2004). Martingale Valuation of Cash Flows for Insurance and Interest Models. North American Actuarial Journal, 8(3), 1-16, https://doi.org/10.1080/10920277.2004.10 596150

Charupat, N., Kamstra, M. J., Milevsky, M. A. (2016). The Sluggish and Asymmetric Reaction of Life Annuity Prices to Changes in Interest Rate. The Journal of Risk and Insurance, 83(3), 519-555, https://doi.org/10.1111/jori.12061

Deelstra, G. (2000). Long-term Returns in Stochastic Interest Rate Models: Applications. Astin Bulletin, 30(1), 123-140, https://doi.org/10.2143/AST.30.1.504629

Dębicka, J., Marciniuk, A. (2014). Comparison of Reverse Annuity Contract and Reverse Mortgage on the Polish Market, in Rusnak, Z., Zmyślona, B., eds., $17^{\text {th }}$ AMSE. Applications of Mathematics and Statistics in Economics. International Science Conference: Poland, 27-31 August 2014. Conference Proceedings Full Text Paper, Wrocław: Wrocław University of Economics Press, pp. 55-64. ISBN 978-83-7695-421-9, https://doi. org/10.15611/amse.2014.17.06

European Central Bank (2018). Yield Curve Index. [Retrieved 2018-02-05] Available at: https://www.ecb.europa.eu/stats/financial_markets_and_interest_rates/euro_area_ yield_curves/html/index.en.html 
Hannewald, K., Post, T., Sherris, M. (2016). Portfolio Choice in Retirement - What is the Optimal Home Equity Release Product? The Journal of Risk and Insurance, 83(2), 421-446, https://doi.org/10.1111/jori.12068

Heilpern, S. (2014). Multiple Life Insurance - Pension Calculation. Proceedings of $17^{\text {th }}$ Applications of Mathematics and Statistics in Economics 2015 International Scientific Conference: Poland, 27-31 August, 2014, pp. 114-122, https://doi.org/10.15611/ amse.2014.17.06

Human Mortality Database (2018). Available at: http://mortality.org. [Retrieved 2018-02-05] James, J., Webber, N. (2000). Interest Rate Modelling. New York: John Wiley \& Sons. ISBN 978-0-471-97523-6.

Luciano, E., Spreeuw, J., Vigna, E. (2016). Spouses' Dependence across Generations and Pricing Impact on Reversionary Annuities. Risks, 4(2), 1-18, https://doi.org/10.3390/ risks4020016

Marciniuk, A. (2009). Modele stóp procentowych i ich zastosowania w ubezpieczeniach (English) (Master thesis). Wrocław: Uniwersytet Ekonomiczny.

Marciniuk, A. (2017). Marriage Reverse Annuity Contract and Reverse Mortgage - Application of a Generalized Model of Reversionary Annuity, in Gardoń, A., Kozyra, C., Mazurek, E., eds., Applications of Mathematics and Statistics in Economics 2017. Conference Proceedings. Wrocław: Wrocław University of Economics Press, pp. 297-306. ISBN 978-83-7695-693-0, https://doi.org/10.15611/amse.2017.20.24

Marciniuk, A., Zimková, E. (2018). Analysis of Potential Marriage Reverse Annuity Contracts Benefit in Slovak Republic. 21st Applications of Mathematics and Statistics in Economics 2018. Conference Proceedings.

Musiela, M., Rutkowski, M. (1988). Martingale Methods in Financial Modelling. Berlin: Springer, https://doi.org/10.1007/b137866

Reality.sk (2018). Prices of Apartments in Czechia and Slovak Republic. [Retrieved 2018-02-05] Available at: https://reality.sk

Reifner, U., Clerc-Renaud, S., Pérez-Carrillo, E. F. et al. (2009). Study on Equity Release Schemes in the EU Part II: Country Reports. Hamburg: Institut für Finanzdienstleistungen e.V. [Retrieved 2019-06-14] Available at: http://www.eurofinas.org

Shao, A. W., Hannewald, K., Sherris, M. (2015). Reverse Mortgage Pricing and Risk Analysis Allowing for Idiosyncratic House Price. Insurance: Mathematics and Economics, 63, 76-90, https://doi.org/10.2139/ssrn.2393813

Toussaint, J., Elsinga, M. (2009). Exploring Housing Asset-based Welfare. Can the UK be Held up as an Example for Europe? Housing Studies, 24(5), 669-692, https://doi.org/10.1080/02673030903083326 